\title{
Pemodelan Matematika SIAS-SI pada Penyebaran Penyakit Malaria Asimtomatik dan Super Infeksi
}

\author{
Muhammad Abdy $^{* 1}$, Hasti Maryam ${ }^{2}$, Wahidah Sanusi ${ }^{3}$ \\ 1,2,3 Jurusan Matematika - FMIPA - Universitas Negeri Makassar \\ e-mail: ${ }^{* 1}$ muh.abdy@unm.ac.id; ${ }^{2}$ hastimaryam47@gmail.com ; ${ }^{3)}$ wahidah.sanusi@unm.ac.id
}

\begin{abstract}
Abstrak
Penelitian ini mengkaji suatu model matematika tipe SIAS-SI pada penyebaran penyakit malaria dengan pengaruh infeksi asimtomatik dan super infeksi. Tujuan penelitian ini adalah menganalisis dan melakukan simulasi pada model untuk memprediksi jumlah kasus malaria yang terbagi kedalam dua kasus, yakni kasus bebas penyakit dan kasus endemik. Penelitian ini merupakan kajian teori yang dilakukan terhadap jurnal penelitian yang telah dilakukan oleh peneliti sebelumnya dan sumber pendukung lainnya untuk mempelajari hal-hal yang berkaitan dengan model SIAS-SI pada penyakit malaria. Dengan menggunakan bilangan reproduksi dasar $\left(R_{0}\right)$, untuk mengetahui status penyebaran penyakit malaria di suatu wilayah. Selain itu, simulasi model pada kasus endemik didapatkan hasil penurunan jumlah kelompok individu terinfeksi asimtomatik pada penyebaran malaria memerlukan waktu yang lama. Sebaliknya pada kasus bebas penyakit, penurunan jumlah kelompok individu terinfeksi asimtomatik memerlukan waktu yang lebih singkat.
\end{abstract}

Kata Kunci: Penyakit Malaria, Model SIAS-SI, Asimtomatik, Super Infeksi

\section{PENDAHULUAN}

Malaria merupakan penyakit yang disebabkan oleh infeksi parasit dari nyamuk Anopheles betina genus Plasmodium. Malaria dapat ditularkan melalui gigitan nyamuk yang terinfeksi, transfusi darah, pemakaian jarum suntik, maupun bawaan dan tergolong penyakit yang sangat mematikan bagi manusia (Resmawan \& Nurwan, 2017). World Malaria Report 2015 menyebutkan bahwa malaria telah menyerang 106 negara di dunia (Kemenkes RI, 2018). Kondisi malaria di Indonesia menunjukkan bahwa masih terdapat 10,7 juta penduduk yang tinggal di daerah endemis menengah dan tinggi malaria. Daerah tersebut terutama meliputi Papua, Papua Barat, dan NTT. Berdasarkan data pada tahun 2017, dari jumlah 514 kabupaten/kota di Indonesia, 266 (52\%) di antaranya wilayah bebas malaria, 172 kabupaten/kota (33\%) endemis rendah, 37 kabupaten/kota (7\%) endemis menengah, dan 39 kabupaten/kota (8\%) endemis tinggi (Kemenkes RI, 2016).

Pemodelan matematika pada penyakit demam berdarah, tuberculosis dan malaria telah dilakukan oleh (Resmawan \& Nurwan, 2017) (Syafruddin \& Noorani, 2013) (Syafruddin \& Noorani, 2013) (Syafruddin, 2015) (Bobby, Syafruddin, et al, 2017) (Rangkuti et al, 2014) (Abdullahi MB et al, 2013) (Laarabi et al, 2012) (Roy M, 2015) (Maryam et al, 2021) (Cai et al, 2017). Penelitian tersebut dilakukan untuk memprediksi jumlah kasus penyakit tersebut. Penelitian yang dilakukan oleh (Resmawan \& Nurwan, 2017) (Rangkuti et al, 2014) (Abdullahi MB et al, 2013) (Laarabi et al, 2012) (Roy M, 2015) (Maryam et al, 2021) (Cai et al, 2017) pada penularan malaria mengasumsikan bahwa penderita malaria yang telah sembuh menjadi kebal dan juga tidak memasukkan kelas infeksi asimtomatik, Kemudian model matematika untuk transmisi penyakit malaria (Fajri et al, 2016) menggambarkan model matematika SIS-SI dalam penyebaran penyakit malaria dengan pemberian pengobatan pada manusia dengan asumsi bahwa manusia yang sembuh dapat tertular penyakit akibat oleh parasit hidup dalam darah dari pengobatan yang tidak memadai atau tidak efektif. Selanjutnya, (Resmawan \& Nurwan, 2017) membahas model matematika penyebaran malaria tipe SEIRS-SEI dengan pemberian perlakuan pada manusia, berupa treatment vaksinasi dan pengobatan. Selain itu, (Cai et al, 2017) membahas model matematika SEIARS-SEI pada penyakit malaria dengan pengaruh infeksi asimtomatik dan super infeksi guna mengukur tingkat sensitivitas penyebaran penyakit malaria terhadap parameter infeksi asimtomatik. Penelitian ini membangun model SIAS-SI pada penyebaran Malaria, analisis dan simulasi pada penularan malaria dengan mempertimbangkan bahwa penderita malaria yang telah sembuh dapat kembali menjadi suspek dan juga memasukkan variabel terinfeksi asimtomatik ke dalam model.

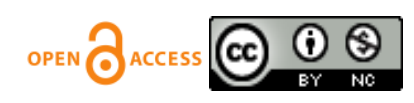




\section{METODE PENELITIAN}

Jenis penelitian yang digunakan adalah penelitian teori dan terapan, yaitu penelitian yang mengkaji teori dan aplikasinya pada penyebaran Malaria. Tahapan penelitian ini adalah membangun model SIAS-SI pada penularan penyakit malaria, model ini menggunakan kompartemen rentan, infeksi dan asimtomatik pada populasi manusia serta kompartemen rentan dan infeksi pada populasi nyamuk. Analisis model menggunakan metode generasi matriks, data yang digunakan pada simulasi merupakan data asumsi dan parameter dipilih berdasarkan studi yang dilakukan oleh beberapa peneliti sebelumnya, dan sebagian parameter lainnya ditentukan melalui asumsi-asumsi sehingga memenuhi salah satu data keadaan $R_{0} \leq 1$ dan $R_{0}>1$. Simulasi model menggunakan Maple untuk memprediksi jumlah kasus malaria pada status bebas penyakit dan endemik.

\subsection{Model Matematika}

\section{HASIL DAN PEMBAHASAN}

Skema alur pemodelan matematika SIAS-SI pada penyebaran penyakit malaria asimtomatik dan super infeksi dapat dilihat pada Gambar 1, yakni:

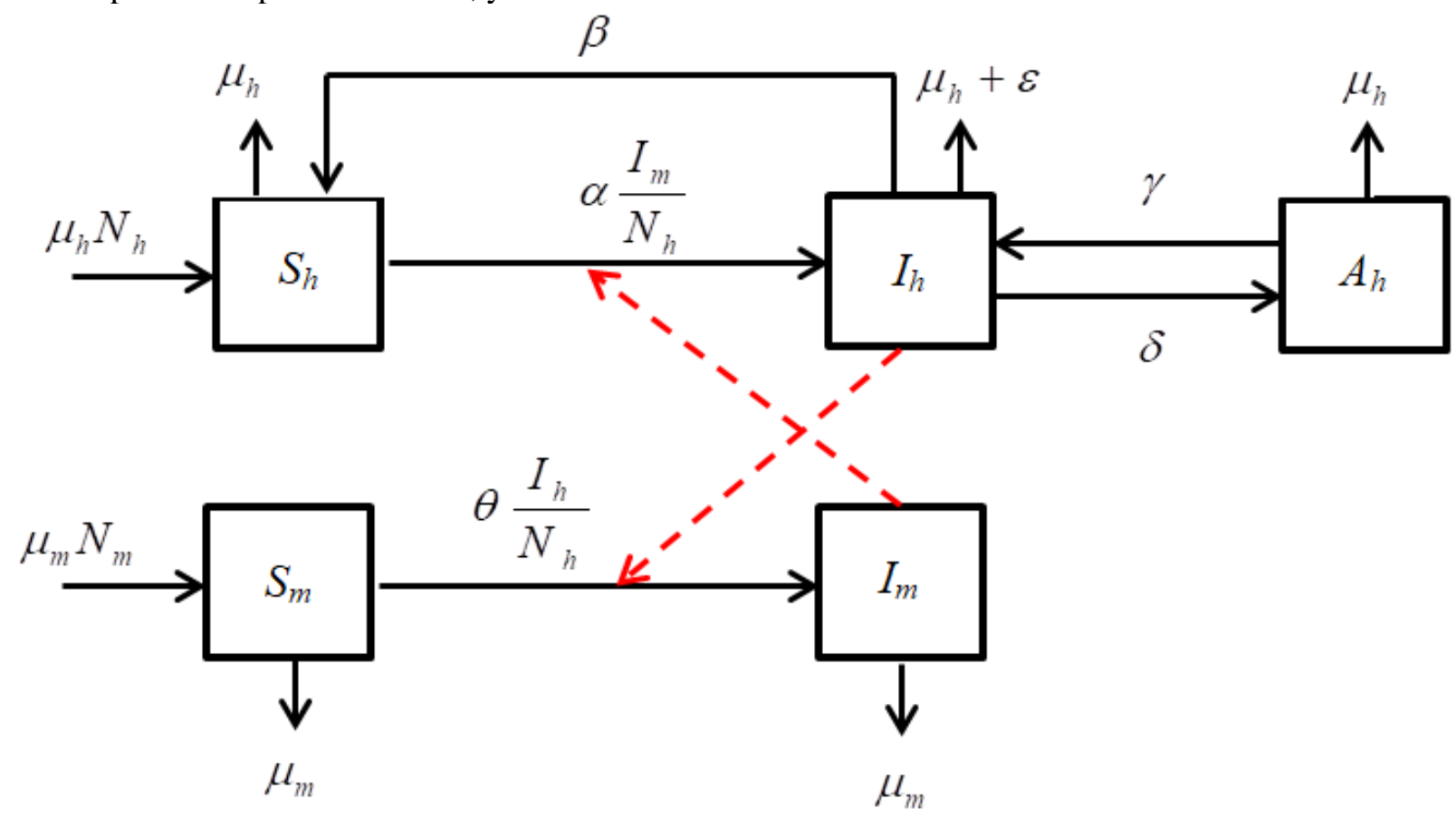

Gambar 1 Skema penularan penyakit malaria model matematika SIAS-SI

Variabel dan parameter yang digunakan disajikan pada Tabel 1 dan Tabel 2.

Tabel 1 Variabel pada Model SIAS-SI Penyebaran Penyakit Malaria Asimtomatik dan Super Infeksi.

\begin{tabular}{|c|l|}
\hline Variabel & \multicolumn{1}{|c|}{ Keterangan } \\
\hline$S_{h}$ & Jumlah individu Susceptible pada manusia \\
\hline$I_{h}$ & Jumlah individu Infected pada manusia \\
\hline$A_{h}$ & Jumlah individu Asymptomatic Infected pada manusia \\
\hline$S_{m}$ & Jumlah Susceptible pada nyamuk \\
\hline$I_{m}$ & Jumlah Infected pada nyamuk \\
\hline
\end{tabular}


https://jurnal.unsulbar.ac.id/index.php/saintifik

Tabel 2 Parameter pada Model SIAS-SI Penyebaran Penyakit Malaria

\begin{tabular}{|c|l|}
\hline Parameter & \multicolumn{1}{c|}{ Keterangan } \\
\hline$N_{h}$ & Laju kelahiran manusia \\
\hline$\alpha$ & Laju terjadinya infeksi pada manusia \\
\hline$\gamma$ & $\begin{array}{l}\text { Konstanta laju superinfeksi dari individu yang terinfeksi namun } \\
\text { tidak terdeteksi (asymptomatic infected). }\end{array}$ \\
\hline$\delta$ & $\begin{array}{l}\text { Laju perpindahan dari individu yang terinfeksi ke kelompok } \\
\text { asimtomatik }\end{array}$ \\
\hline$\beta$ & Konstanta laju pemulihan manusia dari parasit malaria \\
\hline$\theta$ & laju perpindahan nyamuk terpapar ke nyamuk terinfeksi \\
\hline$\mu_{h}$ & Laju konstan kematian manusia secara alami \\
\hline$\varepsilon$ & Laju konstan kematian manusia karena penyakit malaria \\
\hline$N_{m}$ & Laju kelahiran nyamuk \\
\hline$\mu_{m}$ & Laju konstan kematian nyamuk secara alami \\
\hline
\end{tabular}

Berdasarkan Gambar 1, diperoleh model matematika SIAS-SI penyebaran penyakit malaria seperti pada persamaan (1) - (5) yaitu:

$$
\begin{aligned}
& \frac{d S_{h}}{d t}=\mu_{h} N_{h}+\beta I_{h}-\left(\mu_{h}+\alpha \frac{I_{m}}{N_{h}}\right) S_{h}, \\
& \frac{d I_{h}}{d t}=\alpha \frac{I_{m}}{N_{h}} S_{h}+\gamma A_{h}-\left(\beta+\delta+\mu_{h}+\varepsilon\right) I_{h}, \\
& \frac{d A_{h}}{d t}=\delta I_{h}-\left(\gamma+\mu_{h}\right) A_{h}, \\
& \frac{d S_{m}}{d t}=\mu_{m} N_{m}-\left(\mu_{m}+\theta \frac{I_{h}}{N_{h}}\right) S_{m}, \\
& \frac{d I_{m}}{d t}=\theta \frac{I_{h}}{N_{h}} S_{m}-\mu_{m} I_{m} .
\end{aligned}
$$

\subsection{Analisis Model}

Titik kesetimbangan sistem (1-5) diperoleh dengan cara menyelesaikan persamaan:

$$
\frac{d S_{h}}{d t}=0, \quad \frac{d I_{h}}{d t}=0, \quad \frac{d A_{h}}{d t}=0, \quad \frac{d S_{m}}{d t}=0, \quad \frac{d I_{m}}{d t}=0 .
$$

Dengan demikian,

$$
\begin{aligned}
& \mu_{h} N_{h}+\beta I_{h}-\left(\mu_{h}+\alpha \frac{I_{m}}{N_{h}}\right) S_{h}=0, \\
& \alpha \frac{I_{m}}{N_{h}} S_{h}+\gamma A_{h}-\left(\beta+\delta+\mu_{h}+\varepsilon\right) I_{h}=0, \\
& \delta I_{h}-\left(\gamma+\mu_{h}\right) A_{h}=0, \\
& \mu_{m} N_{m}-\left(\mu_{m}+\theta \frac{I_{h}}{N_{h}}\right) S_{m}=0,
\end{aligned}
$$


$\theta \frac{I_{h}}{N_{h}} S_{m}-\mu_{m} I_{m}=0$

\subsubsection{Titik Kesetimbangan Bebas Penyakit $\left(x_{d f e}\right)$}

Titik kesetimbangan bebas penyakit merupakan keadaan dimana penyakit menular tidak menyebar dalam suatu populasi, dan terjadi pada saat $I_{h}=A_{h}=I_{m}=0$ sehingga diperoleh titik kesetimbangan $x_{d f e}$

$$
x_{d f e}\left(S_{h}, I_{h}, A_{h}, S_{m}, I_{m}\right)=\left(N_{h}, 0,0, N_{m}, 0\right)
$$

\subsubsection{Titik Kesetimbangan Tidak Bebas Penyakit $\left(x_{e e}\right)$}

Titik kesetimbangan endemik merupakan keadaan saat penyakit menular menyebar dalam suatu populasi dan terjadi saat $I_{h}, A_{h}, I_{m}>0$. Misalkan rata-rata laju infeksi pada populasi manusia adalah $r_{h}$ dan pada nyamuk adalah $r_{m}$ dengan nilai,

$$
\begin{aligned}
& r_{h}=\alpha \frac{I_{m}}{N_{h}}, \\
& r_{m}=\theta \frac{I_{h}}{N_{h}}
\end{aligned}
$$

Sehingga diperoleh titik kesetimbangan $x_{e e}$

$x_{e e}\left(S_{h}, I_{h}, A_{h}, S_{m}, I_{m}\right)=\left(S_{h}^{* *}, I_{h}^{* *}, A_{h}^{* *}, S_{m}^{* * *}, I_{m}^{* * *}\right)$

dengan,

$S_{h}^{* * *}=\frac{c_{2}\left(c_{1} c_{3}\left(\mu_{h}+r_{h}\right)-r_{h} \beta c_{3}-\gamma \delta\left(\mu_{h}+r_{h}\right)\right)+\beta r_{h} c_{2} c_{3}}{\left(c_{1} c_{3}\left(\mu_{h}+r_{h}\right)-r_{h} \beta c_{3}-\gamma \delta\left(\mu_{h}+r_{h}\right)\right)\left(\mu_{h}+r_{h}\right)}$,

$I_{h}^{* *}=\frac{r_{h} c_{2} c_{3}}{c_{1} c_{3}\left(\mu_{h}+r_{h}\right)-r_{h} \beta c_{3}-\gamma \delta\left(\mu_{h}+r_{h}\right)}$,

$A_{h}^{* *}=\frac{\delta r_{h} c_{2}}{c_{1} c_{3}\left(\mu_{h}+r_{h}\right)-r_{h} \beta c_{3}-\gamma \delta\left(\mu_{h}+r_{h}\right)}$,

$S_{m}^{* *}=\frac{\mu_{m} N_{m}}{\left(\mu_{m}+r_{m}\right)}$,

$I_{m}^{* *}=\frac{\mu_{m}}{r_{m}}$.

dengan syarat:

$c_{1} c_{3}\left(\mu_{h}+r_{h}\right)>r_{h} \beta c_{3}+\gamma \delta\left(\mu_{h}+r_{h}\right)$

\subsubsection{Penentuan Bilangan Reproduksi Dasar Model $\left(R_{0}\right)$}

Bilangan reproduksi dasar, dinotasikan dengan $R_{o}$ adalah nilai harapan banyaknya populasi rentan yang menjadi terinfeksi tiap satuan waktu. Untuk menentukan bilangan reproduksi dasar digunakan pendekatan The Next Generation Matrix. The Next Generation Matrix untuk sistem persamaan (1-5) didefinisikan sebagai:

$$
R_{o}=\rho\left(\mathbf{F} \cdot \mathbf{V}^{-1}\right)
$$

Dengan $\rho\left(\mathbf{F} . \mathbf{V}^{-\mathbf{1}}\right)$ merupakan spektral radius dari matriks $\mathbf{F} . \mathbf{V}^{-\mathbf{1}}$

Spektral radius dari matriks next generation $\mathbf{F} . \mathbf{V}^{-1}$ adalah :

$$
\pm \frac{\sqrt{c_{1} \mu_{m} c_{6} S_{m} c_{4} S_{h}}}{c_{1} \mu_{m}}
$$

Sehingga bilangan reproduksi dasar $R_{o}$ yaitu: 


$$
R_{0}=\frac{\sqrt{c_{1} \mu_{m} c_{6} S_{m} c_{4} S_{h}}}{c_{1} \mu_{m}}
$$

Dengan,

$$
c_{1}=\left(\beta+\delta+\mu_{h}+\varepsilon\right), \quad c_{4}=\frac{\alpha}{N_{h}}, \quad c_{6}=\frac{\theta}{N_{h}} \text {. }
$$

Selanjutnya dengan substitusi titik tetap bebas penyakit (11) pada persamaan (17), diperoleh

$$
R_{0}=\sqrt{\frac{\theta \alpha N_{m}}{N_{h}\left(\beta+\delta+\mu_{h}+\varepsilon\right) \mu_{m}}}
$$

Persamaan (18) merupakan nilai ambang batas epidemik yang akan menjadi tolak ukur tingkat penyebaran malaria dalam populasi.

\section{SIMULASI}

Pada bagian simulasi ini, diamati dinamika populasi dalam kondisi ketika $R_{0} \leq 1$ dan $R_{0}>1$. Dalam hal ini, $R_{0}$ merupakan bilangan reproduksi yang didefinisikan pada persamaan (18). Simulasi dilakukan untuk menunjukkan adanya pengaruh treatment berupa pengobatan pada manusia terhadap dinamika populasi manusia dan populasi nyamuk. Parameter dipilih berdasarkan studi yang dilakukan oleh beberapa peneliti sebelumnya, dan sebagian parameter lainnya ditentukan melalui asumsi-asumsi sehingga memenuhi salah satu data keadaan $R_{0} \leq 1$ dan $R_{0}>1$. Nilai-nilai parameter yang memenuhi keadaan $R_{0} \leq 1$ disajikan pada tabel 4, dan nilai-nilai parameter yang memenuhi keadaan $R_{0}>1$ disajikan pada tabel 5 serta nilai awal populasi disajikan pada Tabel 3.

Tabel 3 Nilai variabel model SIAS-SI pada penyakit malaria

\begin{tabular}{|c|c|c|}
\hline Variabel & Nilai & Referensi \\
\hline$S_{h}$ & 1000 & Asumsi \\
\hline$I_{h}$ & 500 & Asumsi \\
\hline$A_{h}$ & 200 & Asumsi \\
\hline$S_{m}$ & 10000 & Asumsi \\
\hline$I_{m}$ & 250 & Asumsi \\
\hline
\end{tabular}

Tabel 4 Nilai parameter $R_{0} \leq 1$ model SIAS-SI pada penyakit malaria

\begin{tabular}{|c|c|c|c|}
\hline Parameter & Nilai & Satuan & Referensi \\
\hline$N_{h}$ & 1700 & Orang/waktu $^{-1}$ & Asumsi \\
\hline$\alpha$ & 0,010 & Waktu $^{-1}$ & Chitnis et al.,2006 \\
\hline$\gamma$ & 0,005 & Waktu $^{-1}$ & Cai L, 2017 \\
\hline$\beta$ & 0,09 & Waktu $^{-1}$ & Cai L, 2017 \\
\hline$\delta$ & 0,91 & Waktu $^{-1}$ & Asumsi \\
\hline$\mu_{h}$ & 0,004 & Waktu $^{-1}$ & Agusto et al., 2012 \\
\hline$\varepsilon_{h}$ & 0,005 & Waktu & Agusto et al., 2012 \\
\hline$N_{m}$ & 7700 & Nyamuk/waktu $^{-1}$ & Asumsi \\
\hline$\theta$ & 0,072 & Waktu & \\
\hline$\mu_{m}$ & 0.11 & Waktu & \\
\hline
\end{tabular}


Tabel 5 Nilai parameter $R_{0}>1$ model SIAS-SI pada penyakit malaria

\begin{tabular}{|c|c|c|c|}
\hline Parameter & Nilai & Satuan & Referensi \\
\hline$N_{h}$ & 1700 & Orang/waktu $^{-1}$ & Asumsi \\
\hline$\alpha$ & 0,70 & Waktu $^{-1}$ & Asumsi \\
\hline$\gamma$ & 0,005 & Waktu $^{-1}$ & Cai L, 2017 \\
\hline$\beta$ & 0,09 & Waktu $^{-1}$ & Asumsi \\
\hline$\delta$ & 0,91 & Waktu $^{-1}$ & Traore B, 2017 \\
\hline$\mu_{h}$ & 0,0016 & Waktu $^{-1}$ & Agusto et al., 2012 \\
\hline$\varepsilon_{h}$ & 0,005 & Waktu & Asumsi \\
\hline$N_{m}$ & 7700 & Nyamuk/waktu $^{-1}$ & Cai L, 2017 \\
\hline$\theta$ & 0,09 & Waktu & Traore B, 2017 \\
\hline$\mu_{m}$ & 0.11 & Waktu & \\
\hline
\end{tabular}

Tabel 6 Hasil simulasi efektivitas pengobatan pada manusia terhadap bilangan reproduksi dasar $R_{0} \leq 1$

\begin{tabular}{|c|c|}
\hline Parameter $\beta$ & $R_{0}$ \\
\hline 0,09 & 0,1916462082 \\
\hline 0,50 & 0.1616049340 \\
\hline 0,90 & 0.1427346665 \\
\hline
\end{tabular}

Pada populasi manusia yang ditunjukkan pada Gambar 2, jika efektivitas pengobatan pada manusia ditingkatkan, maka banyaknya manusia yang terinfeksi dan asimtomatik mengalami penurunan,sementara manusia yang sembuh dan kembali rentan dari penyakit mengalami peningkatan.
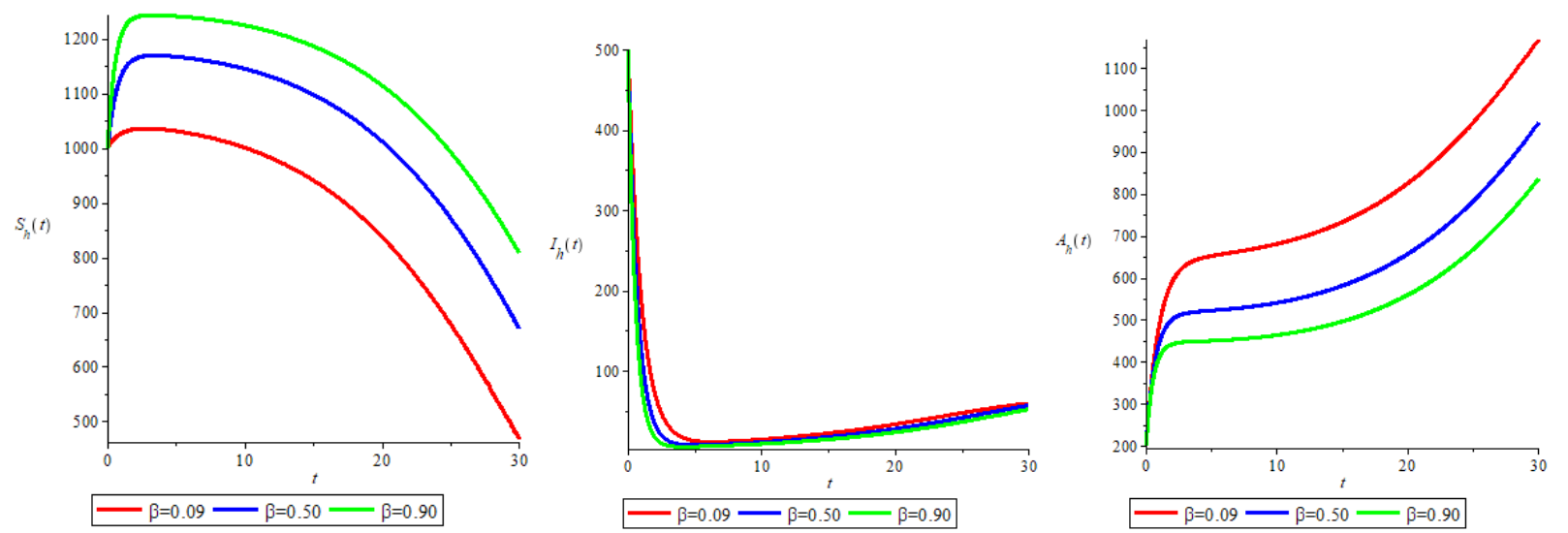

Gambar 2 Dinamika populasi manusia karena adanya pengobatan pada manusia

Pada populasi nyamuk yang ditunjukkan pada Gambar 3, jika efektivitas pengobatan pada manusia ditingkatkan, maka banyaknya nyamuk terinfeksi mengalami penurunan walau tidak terlihat signifikan, sementara nyamuk yang rentan mengalami peningkatan. 

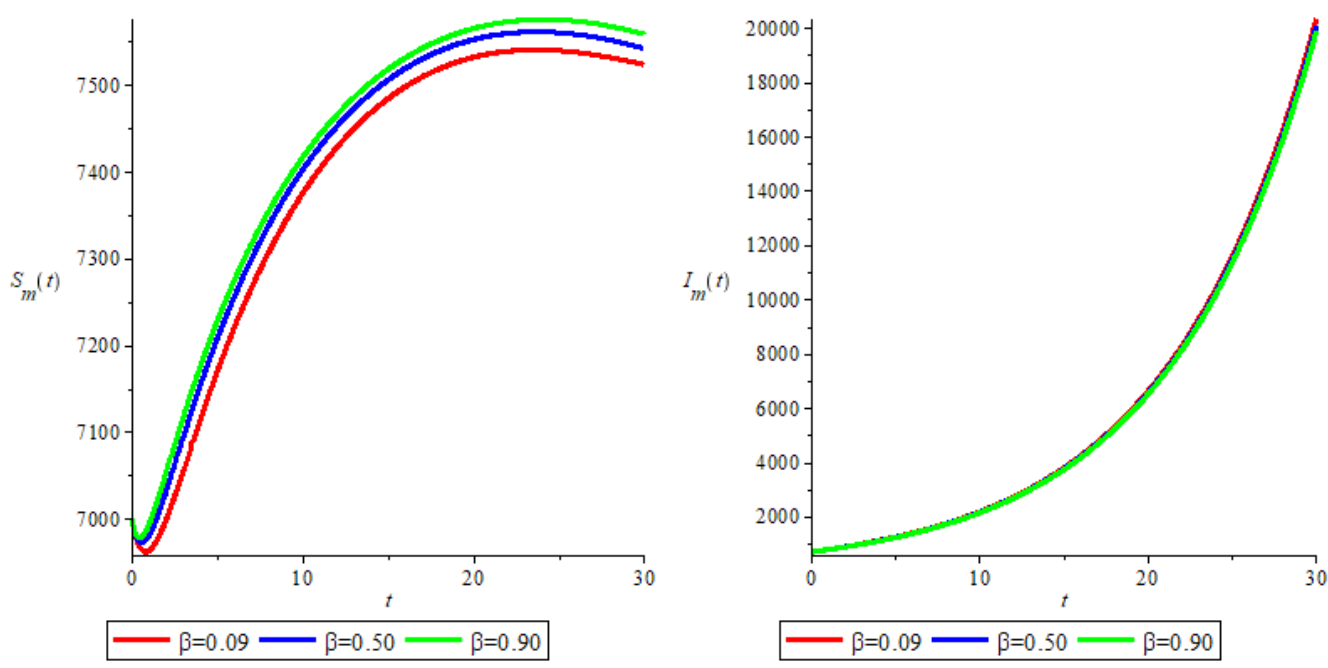

Gambar 3 Dinamika populasi nyamuk karena adanya pengobatan pada manusia

Tabel 7 Hasil simulasi efektivitas pengobatan pada manusia terhadap bilangan reproduksi dasar $R_{0}>1$

\begin{tabular}{|c|c|}
\hline Parameter $\beta$ & $R_{0}$ \\
\hline 0,09 & 1.605337575 \\
\hline 0,50 & 1.353228748 \\
\hline 0,90 & 1.194992499 \\
\hline
\end{tabular}

Pada populasi manusia yang ditunjukkan pada Gambar 4, jika efektivitas pengobatan pada manusia ditingkatkan, maka banyaknya manusia yang terinfeksi dan asimtomatik mengalami penurunan,sementara manusia yang sembuh dan kembali rentan dari penyakit mengalami peningkatan.
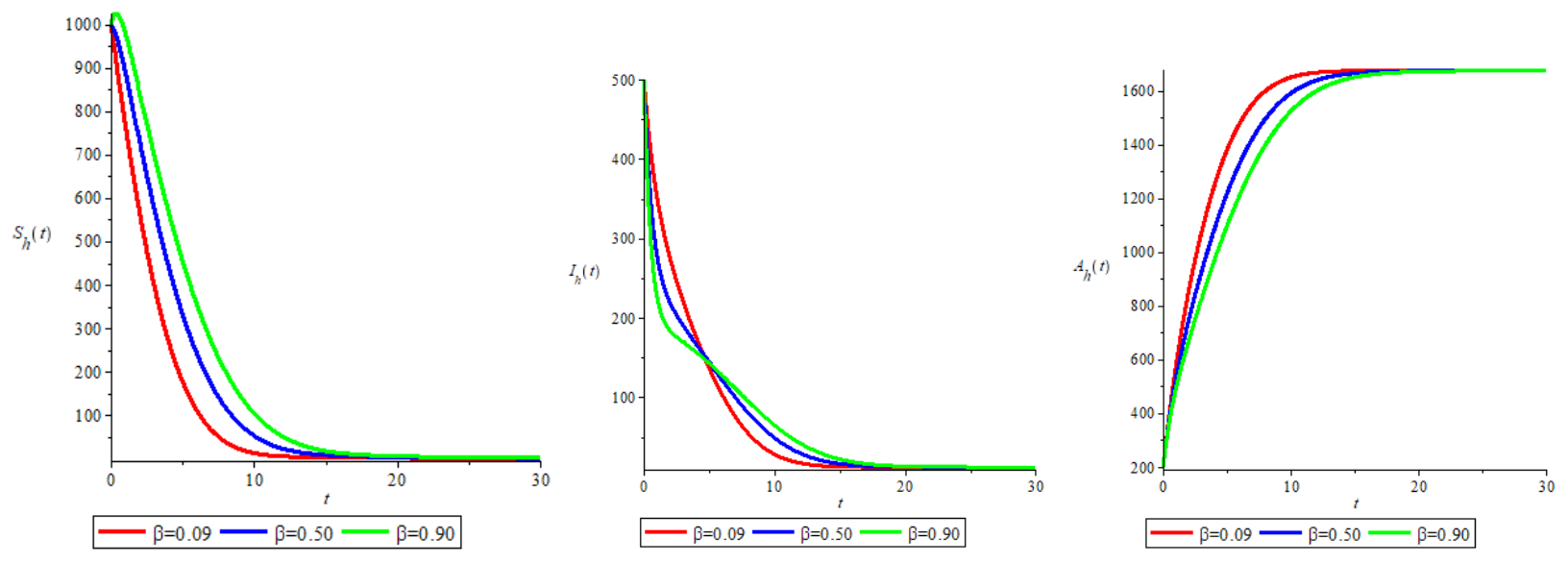

Gambar 4 Dinamika populasi manusia karena adanya pengobatan pada manusia

Pada populasi nyamuk yang ditunjukkan pada Gambar 5, jika efektivitas pengobatan pada manusia ditingkatkan, maka banyaknya nyamuk terinfeksi mengalami penurunan walau tidak terlihat signifikan, sementara nyamuk yang rentan mengalami penurunan. 

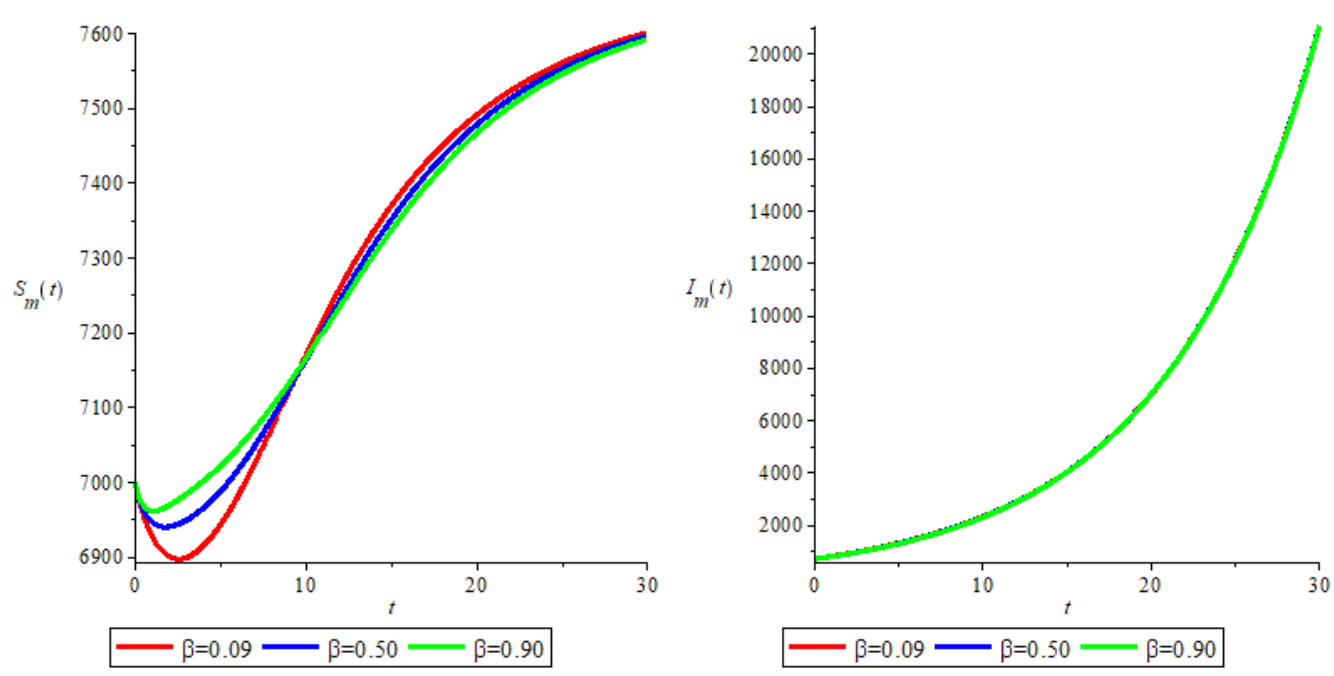

Gambar 5 Dinamika populasi nyamuk karena adanya pengobatan pada manusia

\section{KESIMPULAN}

Simulasi dan interpretasi model matematika penyakit malaria dengan infeksi asimtomatik dan super infeksi pada populasi yaitu Penularan Malaria dapat disajikan dalam model matematika SIAS-SI. Analisis model memberikan gambaran titik kestimbangan penularan malaria, yang berarti penyakit malaria bertahan pada jumlah tersebut. Pada penelitian ini juga diperoleh bahwa titik kesetimbangan bebas penyakit bersifat stabil asimtotik jika $R_{0} \leq 1$ dan titik kesetimbangan endemik bersifat stabil asimtotik jika $R_{0}>1$. Bilangan reproduksi dasar memberikan gambaran keadaan penularan malaria di suatu wilayah yaitu status non endemik atau endemik malaria. Hasil simulasi memberikan gambaran prediksi jumlah kasus malaria di suatu wilayah, yang dapat dijadikan sebagai acuan bagi pemerintah untuk melakukan penanggulangan penyakit malaria dimasa yang akan datang.

\section{DAFTAR PUSTAKA}

Abdullahi MB, Hasan YA, Abdullah FA. 2013. A Mathematical Model of Malaria and The Effectiveness of Drugs. Applied Mathematical Sciences. 7(62):30793095.

Bobby, Syafruddin, dkk. 2017. Analisis Survival Pada Penderita Demam Berdarah Dengue (DBD) Dengan Menggunakan Regresi Cox Di RSU Sawerigading Palopo. PKPT DIKTI 2017.

Cai L, Li X, Tuncer N, Maia M, Lashari AA. 2017. Optimal Control of a Malaria Model with Asymptomatic Class and Superinfection. Mathematical Biosciences. doi/10.1016/j.mbs.2017.03.00.

H Maryam, M Abdy, S Side, 2021. SEIAS-SEI model on asymptomatic and super infection malaria with imperfect vaccination, Journal of Physics: Conference Series 1918 (4), 042028

Kemenkes RI, 2016. Infodatin Malaria http://www.depkes.go.id/article/view/16090700001/infodatinmalaria.html. [Diakses 18 April 2019].

Kemenkes RI, 2018. Hari Malaria Sedunia, Pemerintah Perluas Wilayah Bebas Malaria. http://www.depkes.go.id/article/view/18043000010/hari-malaria-sedunia-pemerintah-perluas-wilayahbebas-malaria.html. diakses tanggal 18 April 2019.

Laarabi H, Labriji EH, Rachik M, Kaddar A. 2012. Optimal Control of an Epidemic Model with a Saturated Incidence Rate. Modeling and Control. 17(4): 448459.

Laneri K, 2015, "Dynamical Malaria Models Reveal How Immunity Buffers Effect of Climate Variability", DOI: 10.1073/pnas.1419047112.

N. Fajri, P. Sianturi, T. Bakhtiar. 2016. Model Matematika SIS-SI Dalam Penyebaran Penyakit Malaria dengan Vaksinasi Taksempurna. Jurnal Manejemen dan Agribisnis,Vol.15(2). p(51-62). 
Rangkuti, Y.M., Side, S., Noorani, M.S.M., 2014.Numerical analytic solution of SIR model of dengue fever diseasein South Sulawesi using homotopy perturbation method and variational iteration method. Journal of Mathematical and Fundamental Sciences.46A(1),91-105.

Resmawan \& Nurwan. 2017. Konstruksi Bilangan Reproduksi pada Model Epidemik SEIRS-SEI Penyebaran Malaria dengan Vaksinasi dan Pengobatan. DOI:10.24198/jmi.v13.n2.12332.105-114

Roy M, 2015, Predictability of Epidemic Malaria Under Non-Stasionary Conditions with Process-based Models Combining Epidemilogical Updates dan Climate Variability, DOI: 10.1186/s12936-015-0937-3

Syafruddin, S. 2015. A Susceptible-Infected-Recovered Model and Simulation for Transmission of Tuberculosis, Advanced Science Letters.Volume 21(2):137-139

Syafruddin, S. and M.S.M Noorani. 2013. A SIR model for spread of dengue fever disease (simulation for south sulawesi Indonesia and selangor Malaysia). World journal of modeling and simulation; Vol. 9 (2):96-105.

Syafruddin, S. and M.S.M Noorani. 2013. Lyapunov function of SIR and SEIR model for transmission of dengue fever disease. International Journal of Simulation and Process Modelling (IJSPM). Vol. 8, (2/3):177-184. 